\title{
Inhibition of Trimethylamine N-oxide Reductase Formation by Nitrate in Escherichia coli
}

\author{
Morihiko SAKaguchi* and Akira Kawal* \\ (Received May 28, 1975)
}

\begin{abstract}
The effects of nitrate on induced formation of trimethylamine N-oxide (TMO) reductase as well as on cell growth were examined in Escherichia coli. The addition of nitrate to a culture caused significant inhibition of the reductase formation in cells. Growth of cells was promoted by nitrate to the same extent as by TMO.

It was suggested that the combination of TMO as an inducer with cell enzyme induction systems obeys Michaelis-Menten kinetics. The inhibition of the enzyme formation by nitrate was proved to be non-competitive in nature. The inhibitor added to assay mixtures, however, did not affect at all the activity of the induced enzyme itself.
\end{abstract}

In earlier studies on bacterial reduction of trimethylamine N-oxide (TMO), CASTELL and SNOW ${ }^{1)}$ described that factors which influence TMO-reducing activity of cells include $\mathrm{pH}$, temperature, sodium chloride, nitrite, and nitrate. Among these factors it is nitrate that took our particular interest, since nitrate was reported to inhibit the reducing activity of Escherichia coli ${ }^{1,2)}$ and also to have a promotive effect on the growth of cells ${ }^{3)}$. Facultative anaerobes such as Escherichia and Salmonella are able to grow faster in the presence of TMO than in the absence, ${ }^{4,5}$ Trimethylamine $\mathrm{N}$-oxide reductase, which is responsible for the reduction of TMO to trimethylamine (TMA), was characterized to be a de novo synthetic ${ }^{4}$ and membrane-bound enzyme. ${ }^{\text {") }}$

The present paper mainly deals with inhibition of TMO reductase formation by nitrate in $E$. coli.

\section{Material and Methods}

Escherichia coli (IFO 3301) was grown under the same condition as described previously. ${ }^{4}$ Uniess otherwise mentioned, TMO was added to a culture in the concentration of $7.3 \times 10^{-2} \mathrm{M}$ when cells grew up to $0.40-0.45$ of optical density at $660 \mathrm{~nm}$ (O.D. 660). Preparation of cell suspension, assay of TMO reductase activity, and determination of residual TMO in the culture were all the same as done previously. ${ }^{4}$ ) Nitrate was added as sodium nitrate.

\section{Results and Discussion}

Effect of nitrate on induced formation of TMO reductase and on growth of cells As reported in the previous paper, ${ }^{4)}$ TMO reductase was rapidly formed when cells accepted

* The Research Institute for Food Science, Kyoto University, Uji, Kyoto, Japan (坂口守彦 - 河合 章：京都大学食糨科学研究所) 
TMO as an inducer in cultures. In order to examine the effect of nitrate on the induced formation of the enzyme, nitrate was added to the culture $\left(7.2 \times 10^{-2} \mathrm{M}\right)$ at $0 \mathrm{~min}$ together with TMO or at $45 \mathrm{~min}$ after feeding the oxide. The enzyme activity and growth of cells are illustrated in Fig. 1 and 2, respectively. In another experiment nitrate was added at $0 \mathrm{~min}$, followed by TMO at $45 \mathrm{~min}$. The enzyme activity and growth of cells are given in Fig. 3 and 4, respectively.

In Fig. 1 it was observed that feeding TMO only at 0 min to the culture made significant increase of the enzyme formation in cells. The formation in the simultaneous addition of nitrate and TMO at $0 \mathrm{~min}$ was allowed to increase slightly until about $40 \mathrm{~min}$, and heavily inhibited thereafter. The addition of nitrate at $45 \mathrm{~min}$ after the cultivation with TMO ceased to form the enzyme more rapidly, compared with the case of the simultane-

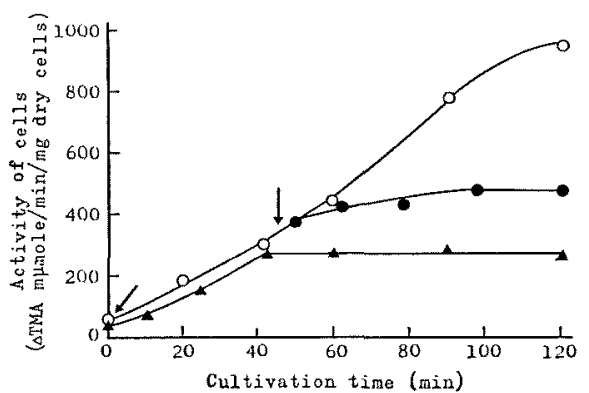

Fig. 1. Effect of nitrate on the enzyme formation in cells.

Nitrate was given to a culture at 0 or $45 \mathrm{~min}$, as indicated by arrow. and $\longrightarrow$, with nitrate; $O-0$, without nitrate.

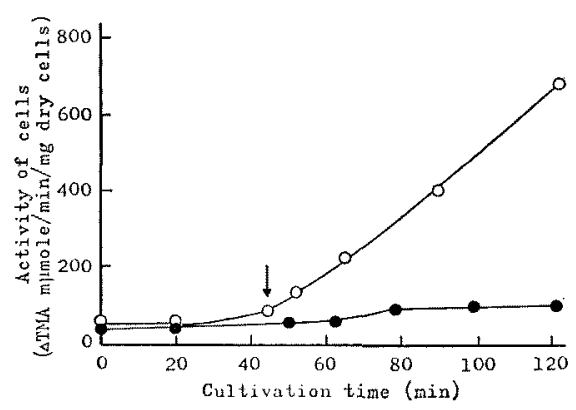

Fig. 3. Enzyme formation of cells in a culture containing nitrate.

After the addition of nitrate at $0 \mathrm{~min}$, TMO was given at $45 \mathrm{~min}$, as indicated by arrow. - - with nitrate; $0-0$, without nitrate.

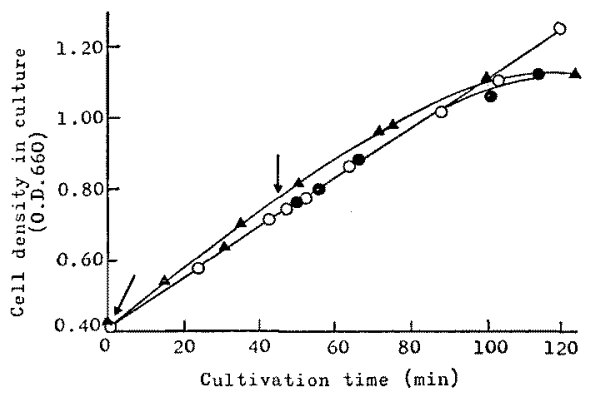

Fig. 2. Effect of nitrate on growth of cells Nitrate was given to a culture at 0 or $45 \mathrm{~min}$, as indicated by arrow.

$\Delta-\Delta$ and -0 , with nitrate; $0-0$, without nitrate.

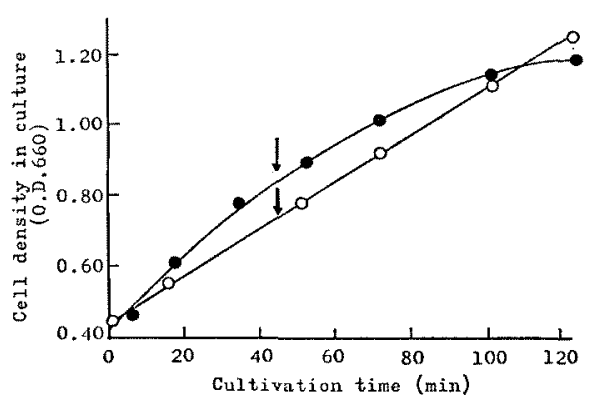

Fig. 4. Growth of cells in a culture containing nitrate.

After the addition of nitrate at $0 \mathrm{~min}$, TMO was given at $45 \mathrm{~min}$, as indicted by arrow. - , with nitrate; $\mathrm{O}-\mathrm{O}$, without nitrate. 
ous addition at 0 min. In Fig. 3 the enzyme formation in the culture lacking nitrate increased dramatically by the supplementation of TMO at $45 \mathrm{~min}$. Nitrate previously added at 0 min exhibited high interference with the formation which should be revealed by TMO fed at $45 \mathrm{~min}$. The result obtained from the experiment indicates that the enzyme formation is strongly inhibited by nitrate during the cultivation of cells.

Promotion of cell growth by supplying cultures with TMO was reported previously." A preliminary experiment on the growth had shown that cells accepted only nitrate in the culture grew fast in a completely same extent as observed on nitrate plus TMO. As given in Fig. 2, the addition of nitrate together with TMO at 0 min hardly brought about the greater growth than that of TMO only. Nitrate added at $45 \mathrm{~min}$ also failed to enhance the growth of cells in the culture previously supplemented with TMO at $0 \mathrm{~min}$. It was confirmed in Fig. 4 that the addition of nitrate was promotive in growth but that the subsequent supplementation of TMO at $45 \mathrm{~min}$ did not show any further promotion. Trimethylamine $\mathrm{N}$-oxide fed at $45 \mathrm{~min}$ enabled cells to increase up to almost the same growth level as they maintained by nitrate plus TMO in the culture. Incidentally, cell density never exceeded 1.0 of O.D. 660 in the culture without any supplement, as reported previously.; These findings therefore are taken to indicate that nitrate promotes the growth of cells as high as TMO does under the present culture condition.

Type of the inhibition of the enzyme formation by nitrate Concerning participation of nitrate in the inhibition, we determined whether or not the inhibitor competes with TMO as the inducer of the enzyme. Before going into the determination, we measured the inducer amounts in the culture during cultivation since actually a concentration of the inducer was recognized to be reduced by the induced enzyme appearing in cells." Table 1 shows the situation of change in the inducer with three different concentrations initially added to the culture $\left(2.2 \times 10^{-3}, 7.3 \times 10^{-3}\right.$ and $\left.10.0 \times 10^{-3} \mathrm{M}\right)$. When an initial concentration being as low as $2.2 \times 10^{-3} \mathrm{M}$, the inducer was completely consumed within $41 \mathrm{~min}$. Ninety percent of the inducer with a concentration of $7.3 \times 10^{-3} \mathrm{M}$ and $60 \%$ with that of $10.0 \times 10^{-3} \mathrm{M}$ were lost for about $65 \mathrm{~min}$. Only $30 \%$ of the inducer at a relatively high concentration of $7.3 \times 10^{-2} \mathrm{M}$ was reduced even for $120 \mathrm{~min}$, as seen in the previous report. ${ }^{4)}$ In earlier stages of cultivation the inducer was less reduced if initial

Table 1. Decrease in the inducer concentrations during cultivation

\begin{tabular}{cccccc}
\hline $\begin{array}{c}2.2 \times 10^{-3} M^{*} \\
\text { Time }\end{array}$ & $\begin{array}{c}\text { Residual } \\
(\%)\end{array}$ & $\begin{array}{c}\text { Time } \\
(\mathrm{min})\end{array}$ & $\begin{array}{c}7.3 \times 10^{-3} \mathrm{M}^{*} \\
\text { Residual } \\
(\%)\end{array}$ & $\begin{array}{c}\text { Time } \\
(\mathrm{min})\end{array}$ & $\begin{array}{c}10.0 \times 10^{-3} \mathrm{M}^{*} \\
\text { Residual } \\
(\%)\end{array}$ \\
\hline 1 & 100 & 0 & 100 & 3 & 100 \\
11 & 93 & 10 & 98 & 15 & 95 \\
21 & 68 & 20 & 91 & 27 & 88 \\
41 & 0 & 40 & 59 & 45 & 64 \\
66 & 0 & 65 & 10 & 64 & 41 \\
\hline
\end{tabular}

\footnotetext{
* initial concentration in a culture.
} 
concentrations are relatively high in the culture. Thus $15 \mathrm{~min}$ of the period was employed so that a possibility of the remarkable decrease in initial concentrations of the inducer can practically be excluded.

With or without nitrate, cells accepted the inducer in the culture with concentrations of $0.9 \times 10^{-3}-10.0 \times 10^{-3} \mathrm{M}$ to be cultivated for the above-mentioned period. The enzyme activity of cells $(v) /$ the inducer concentration $(s)$ was plotted against $s$, as shown in Fig. 5. The plot gave a straight line, indicating that the combination of the inducer with induction systems in cells obeys Michaelis-Menten kinetics. ${ }^{7)}$ The plots in the presence of nitate were also linear; the higher inhibition was brought about at $7.0 \times 10^{-3} \mathrm{M}$ than at $2.1 \times 10^{-3} \mathrm{M}$ of its concentrations. The figure shows that three straight lines cross one another near the origin, strongly suggesting a non-competitive type of the inhibition by nitrate rather than a competitive with the inducer.

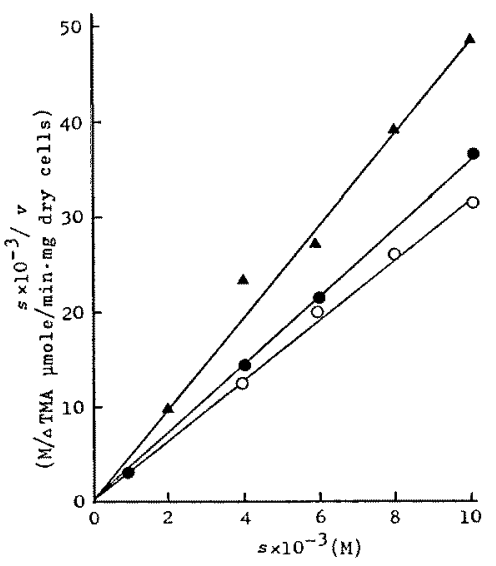

Fig. 5. Non-competitive inhibition of induced formation of the enzyme by nitrate. $s$, inducer concentration; $v$, activity of cells, - , with $2.1 \times 10^{-3} \mathrm{M}$ of nitrate; $\mathbf{\Delta}-\boldsymbol{A}$, with $7.0 \times 10^{-3} \mathrm{M}$ of nitrate; $\mathrm{O}-\mathrm{O}$, without nitrate.

It is still obscure whether the inhibition observed in the experiment is partly or wholly due to nitrite which can be reduced from nitrate during the cultivation. Some tests on this point are now in progress.

Effect of nitrate on the activity of the enzyme induced by TMO CASTELL and SNOW ${ }^{13}$ already reported that the addition of nitrate to a reaction mixture containing TMO as a substrate resulted in the significant inhibition of TMO-reducing activity of $E$. coli resting cells. In view of their finding, we made an attempt to ascertain whether or not nitrate has an inhibitory effect on the enzyme activity itself. Induced cell suspensions prepared after being cultivated for $75 \mathrm{~min}$ in the presence of TMO were incubated with various concentrations of nitrate $\left(1.0 \times 10^{-3}-7.3 \times 10^{-2} \mathrm{M}\right)$ in assay mixtures. The activity thus measured is given in Table 2 . There hardly can be found any difference in the activities 
Table 2. Trimethylamine $\mathrm{N}$-oxide reductase activity in assay mixtures to which nitrate with various concentrations was added

\begin{tabular}{cc}
\hline $\begin{array}{c}\text { Concentration of } \\
\text { nitrate }(\mathrm{M})\end{array}$ & $\begin{array}{c}\text { Activity* } \\
\text { (TMA formed } \mu \text { mole } / \mathrm{min})\end{array}$ \\
\hline $7.3 \times 10^{-2}$ & 2.43 \\
$2.4 \times 10^{-2}$ & 2.60 \\
$4.1 \times 10^{-3}$ & 2.64 \\
$7.0 \times 10^{-4}$ & 2.13 \\
$1.0 \times 10^{-4}$ & 2.24 \\
0 & 2.45 \\
\hline
\end{tabular}

* Reaction was carried out using $3.77 \mathrm{mg}$ dry cells of cell suspensions.

between cells with and without nitrate in the mixtures. It seems to be concluded that nitrate does not inhibit the enzyme activity itself.

On the bases of these evidence, the data presented by CASTELL and SNOw are interpreted as implying that nitrate is unable to inhibit the enzyme activity but the enzyme formation in resting cells of $E$. coli.

\section{Acknowledgement}

We are greatly indebted to Mr. K. MizuguchI, Kyoto Fish Market Co. Ltd. for his technical assistance.

\section{References}

1) C. H. Castell and J. M. Snow: J. Fish. Res. Bd. Canada, 8, 195-206 (1951).

2) K. Nishida and A. Kobayashi: Bull. Fac. Agr. Kagoshima Univ., 2, 113-119 (1953).

3) W. Verhoeven: in "Inorganic Nitrogen Metabolism" (ed. by W. D. McElroY and B. Glass), John Hopkins Press, Baltimore, 1965, pp. 61-86.

4) M. SAKaguchi and A. Kawal: This Bull., 41, 661-665 (1975).

5) K. E. Kim and G. W. Chang: Can. J. Microbiol., 20, 1745-1748 (1974).

6) M. SAKaGuChI and A. KawaI: This Bull,, 41, 707 (1975).

7) M. Dixon and E. C. WebB: in "Enzymes", Longmans, Green and Co., Ltd., London, 1964, pp. $477-536$. 